\title{
YOUTH AND THE SKILLS SYSTEM IN BULGARIA. CAN LIFELONG LEARNING POLICIES ON THE REGIONAL LEVEL COMPENSATE FOR THE MISMATCHES IN THE NATIONAL SKILL SYSTEM?
}

\author{
Dr. Valentina Milenkova, South-West University, Bulgaria \\ E-mail: vmilenkova@gmail.com \\ Dr. Siyka Kovacheva, Plovdiv University, Bulgaria \\ E-mail: siykakovacheva@gmail.com
}

\author{
A R T I C L E I N F O \\ Original Research \\ Received: January, 28.2020. \\ Revised: March, 09.2020. \\ Accepted: March, 17.2020. \\ UDK \\ 37.014.48-053.81(497.2) \\ Keywords: \\ young adults, \\ youth transitions, \\ skills system, \\ lifelong learning policies, \\ Bulgaria, \\ regional context.
}

doi: 10.5937/IJCRSEE2001049M

\begin{abstract}
A B S T R A C T
The present article is a study of the opportunities and constraints for youth transitions from education to employment vis-a-vi the structural relationships (of compliance and discrepancy) between the sectors of education, training and the labor market. The analysis examines the deficiencies in the coordination of the demand and supply of skills in Bulgaria, which hinder the successful employment integration of the current young generation. The mismatches in the system are highlighted on the national and the regional level where we focus on the contextual cases of Blagoevgrad and Plovdiv functional regions. The paper reveals that there is a discrepancy between labor supply and demand in the skills systems in both regions where less than half of university graduates work in the specialty they have acquired during studies. One of the conclusions of the study is that social changes under way require new strategies and approaches of lifelong learning policies that should go deeper into the regional and local level taking into account both the needs of young people for training throughout their lives and the needs of the regional labor markets.
\end{abstract}

(C) 2020 IJCRSEE. All rights reserved.

\section{INTRODUCTION}

An increasing number of young people in Bulgaria, similar to their peers in Europe, entering the labor market after graduating from secondary and higher education are faced with problems in finding a job. They have difficulty coping with this challenge because they do not have the necessary skills and practical training. They enter the labor market with great expectations but are unprepared for reality. Therefore, employability is a key indicator of the effectiveness of educational institutions and is expressed in the acquired qualifications and skills of graduates to achieve labor market

\footnotetext{
Corresponding Author

Dr.Valentina Milenkova, South-West University, Bulgaria

E-mail: vmilenkova@gmail.com
}

\section{c) $९ ९$}

This work is licensed under a Creative Commons Attribution - NonCommercial - NoDerivs 4.0. The article is published with Open Access at www.ijcrsee.com competitiveness in a regional, national and global context. Employability has a direct impact on the performance of a young person at the start of a job (Benneworth, 2010), and, in accordance with the qualifications, qualities and training achieved, it is related to the ability to adapt and accelerate knowledge, to self-discipline and motivation, and to skills teamwork (McLoughlin and Luca, 2002), that have impact as transferable skills.

The present article is a study of the opportunities and constraints for youth transitions from education to employment visa-vi the structural relationships (of compliance and discrepancy) and the link between knowledge, attainment of qualifications, and the labor market sectors. There are various institutions which develop skills and interact with different social actors who have the potential and resources to influence the process of training young adults and their entry into the labor market. The main research questions are: How lifelong learning policies can help young adults transition from training 
to the labor market? and How is the mismatch between education and the job market shaping the expectations of social actors?

The aim of the analysis is to show the coordination of the seeking and offering skills carried out in the contemporary Bulgarian conditions, which represent a good basis for studying the research questions. This article seeks to address the issue of the development of effective programs that facilitate the integration of young people into dynamic contemporary labor markets. Our view is that similar programs that stimulate the transition from education to employment are a prerequisite for the successful reduction of the proportion of people who are vulnerable and socially distant.

In particular, the analysis is focused on the contextual cases of the Blagoevgrad and Plovdiv functional regions. The article presents the outcomes from the mapping of regional institutions that are responsible for the creation of skills ecology. Different organizations have varying degrees of participation in the process of skills formation. Educational institutions such as vocational schools, colleges and universities, vocational centers are most involved in training and skills formation. On the other hand, employment agencies and labor offices also participate in this process through the implementation of various programs aimed at developing the skills of young adults who have graduated but have no practical experience. An important role in the process of shaping and realizing skills have various business companies and their branch organizations, which are becoming important stakeholders. In this way, the skill system is formed and changes continuously depending on the actors taking part in it as well as from their efforts and activities. At the same time, the whole process takes place in a specific environment characterized by different economic and policy conditions, which also influence the skills system. The specific combination of actors, policies and beneficiaries in the structure of skills that are built, exist and manifest in regional / local conditions can be considered as local / regional ecology of skills (Parreira do Amaral and Kovacheva, 2019).

\section{THEORETICAL FRAMEWORK}

Theories which examine the discrepancy in skills ecology between education and labor market can be combined into two groups. The first group of theories emphasizes the essence of "non-compliance" as a phenomenon. Concrete aspects of the mismatch are being examined, the reasons for its existence, its origins and how it is expressed. The main focus is on the growth of global competition, the rapid technological change, the development of economy that give rise to the mismatch in the skills of people (Cedefop, 2010).

The thesis that skills mismatch refers not only to the lack of skills and knowledge, but also to the overeducation and overskilling of young people is being presented. The mismatch of skills requires time to resolve it, as well as expenses of individuals, business and government investments, taking into account the combination of skills and jobs and the provision of information about mismatches. The skills gap is a function of the level of work and its complexity, while the duration of skills gaps is linked to the need for retraining. In general, mismatch in skills is related to:

- The aging of skills in cases where technological change requires new abilities and knowledge; this can happen for a relatively short time in the working life of a person and can be overcome through the system of lifelong learning.

- "Overeducation" is a phenomenon when people are taking low-skilled jobs while continuing to look for better options for realization.

Skill gaps or even underskilling exist in cases where people do not have the necessary qualification and knowledge. The reasons connected to inadequate training, education and training systems that are not in line with market changes and business cycles.

Besides that, "Mismatch is more relevant for specific groups, such as young people entering the labour market, older workers, females, ethnic minorities and the disabled" (Cedefop, 2010: 7). The emphasis is on the fact that the gap between the structure of training and the needs of the labor market is a major factor to job instability and imbalances. This discrepancy can be seen as a mismatch between labor supply and demand and it creates prerequisite for reducing the adequacy of labor and the rational use of the human factor. As a consequence, the economy is placed in unfavorable situation related to the ineffectiveness of human resources and their potential. In addition, the gap between demand for and supply of skills blocks the growth of GDP and the overall development of society (Federation, Radovic and Djuraskovic, 2015). This group of theories also studies the 
specific sectors of the economy, as well as the nature of the necessary skills that will best and most adequately fit the individual sectors. Analyzes show that between 15 and almost $35 \%$ of those employed in European countries are either undereducated or over-educated, and it may be emphasized that under-education is a more common occurrence than the surplus of education (Morgado et al, 2015). More detailed studies based on representative surveys show a more systematic and comprehensive overview of the state of the labor market and its processes (Schomburg and Teichler 2007; Morgado et al, 2015; Cedefop, 2010). A key conclusion of this group of theories is the need to rethink policies on a European level, to seek adequate approaches in educational institutions, to become the real institutions of LLL, to rethink the concrete measures to update the correlation between training and the realization of young people.

The second group of theories shows the relationship between the individual aspect, emphasizing the individual abilities and the structural aspects related to the actions of institutions in which the personal and community life of the actors takes place. The main objective is to understand young people's market behavior in the institutional environment (Tholen, 2015; Tomlinson, 2017; Boyadjieva and Ilieva-Trichkova 2015), connected to looking for jobs which are relevant to education, skills and ambitions. Discrepancy in skills ecology shows dynamic discrepancy in the complex labor market and is often accompanied by inappropriate search for information, opinions, support; it can be a function of factors other than the type of completed education and specialty. The discrepancy may also be due to the influence of the community environment, the contacts and connections which the young person has built up, the lack of information, the market situation in the choice of education and profession, which are subsequently not relevant to the circumstances.

Lifelong learning is a broader concept than the development of skills and competences in a formal educational institution, which are then applied in the workplace. It refers to a learning process recurring over the whole life course of the individual as underlined in the 1996 UNESCO report (Delors et al, 1996). Since the early stages of the EU policy on lifelong learning (EC, 2000, 2001) the concept and the policies implementing it has expanded to include an understanding of a more humanistic and holistic process of acquiring knowledge, acknowledging the economic, political, cultural, and social needs the young people.

\section{MATERIALS AND METHODS}

The analysis builds upon the results of the project "YOUNG_ADULLLT - 'Policies Supporting Young A Adullts in their Life Course', team coordinator Prof. Marcelo Parreira do Amaral, Ph.D., under the Horizon 2020 Program, 2016-2019. The study used mixed methods of data collection: analysis of official documents and 'grey' literature, quantitative data from Eurostat and other large-scale surveys, as well as local statistics and interviews in depth with policy makers, practitioners and young beneficiaries of lifelong learning programs and initiatives. The research collected empirical data on different levels: global, national, regional and local. One of the important features of the project is its commitment to the functional region a specific amalgam of functional relations between diverse institutions in a particular area (Parreira do Amaral and Kovacheva, 2019). The functional region as a key concept was used in the project to indicate specifics in terms of living conditions, education, institutions that form the skills of young people. It refers to a relational delineation of space that does not necessarily 'reflect geographical particularities or historical events'(OECD, 2016: 14). Rather the boundaries of a functional region are drawn to reflect the various processes, entities and mutual contacts that manifest themselves in their specific characteristics such as people, goods, energy, information, etc. (Klapka, Halás and Tonev, 2013: 2).

The project looked into the embeddedness of the policies in the regional economies and local labour markets in two regions in each of the project partner countries and aimed to study the potential of these policies to enhance young people's resources for developing and implementing their own life projects. The respondents were selected from a variety of LLL policies and projects implemented by public, private institutions and the non-governmental sector in nine European countries (Austria, Bulgaria, Croatia, Finland, Germany, Italy, Portugal, Spain, United Kingdom). The fieldwork consisted of semistructured interviews with regional policy makers and street level professionals and of biographical interviews with young people current or former participants in the policy 
measures. Between April and June 2017, a total of 21 interviews were conducted in Blagoevgrad Functional Region: 11 of them with experts and 10 with the young adults, participating in the four identified projects. Similar number of interviews were conducted in Plovdiv Functional Region (9 with professionals and 12 with young beneficiaries) following the commonly designed sample and interview schedule. In the interviews, the link between LLL programs and the living conditions of young people related to their life strategies was followed. The interviews focused on tracking LLL programs in relation to young people's needs, their potential and hidden resources as a prerequisite for their realization (Milenkova and Kovacheva, 2020).

Access to the young interviewees was secured through the institutions implementing measures related to lifelong learning. The interviews in both regions followed a common strategy starting with an open question prompting the interviewees to present themselves as they wished and tell stories about their lives and then focuses on more specific topics pertaining to their training, educational institutions, teachers, participation in life-long learning projects, job biographies, attempts to find a job, various significant events and personalities that have had a lasting impact on the decisions and transitions within their life projects and expectations. All interviews were fully transcribed and an extended summary in English was provided for each interview and shared among the consortium members. All interviews were coded according to the guidelines developed by Corbin and Strauss (1990).

This article also uses data from the NSI and Eurostat, which show the state of transition from education to employment of young people in Bulgarian conditions. Data from surveys conducted by the Bulgarian Chamber of Commerce, as well as surveys from the Ministry of Education and Science concerning the rating of universities and colleges in the country were used. The data provided are reliable and public and represent a legitimate basis for the conclusions and summaries made.

\section{RESULTS}

Lifelong learning policies target young people in a crucial life stage - at the time associated with the transition from education to work. Transitions is a major concept in sociology of youth which treats youth and young adulthood as a social construct rather than a universal phase of a biologically determined individual development. The key advantage of the 'transitions paradigm' according to Roberts (2018) lies in 'its ability to embed the study of youth within the longer life course'. Most researchers of youth trajectories highlight the changes in post-modern societies in which youth transitions become prolonged and destandardised due to growing risks and insecurity in all life domains (Walther, 2006, Stoilova and Nyagolov, 2016). Education-towork, family and housing transitions often intermingle in young people's life trajectories and a failure in one type creates delays and disadvantages in the other types. Such trends have been established among young people in Bulgaria in the past few decades (Kovacheva, 2001, Stoilova and Nyagolov, 2016; Mitev et al, 2019).

With the transition from a totalitarian to a democratic and a market-oriented system in the country youth activity shifted radically from social and political life to the private economic sector. To date, the main challenges facing this group are the difficulties to find work, the insufficient income levels and the low quality of working conditions - as a sphere where the consequences of the economic crisis most directly felt. Young people in Bulgaria are one of the groups of young men and women that make the latest entry into the labor market compared to other EU countries (Eurofound, 2014). Similar to other countries in South and Eastern Europe, they face both structural and institutional barriers in front of their efforts to obtain quality employment (Boyadzieva and Ilieva-Trichkova, 2019). After completing their education, most of the young people in Bulgaria have no practical and working experience, which leads to their more difficult integration into the labor market. They often face the inability to accumulate work experience and fall into a vicious circle - they are not being hired because they do not have work experience, but they cannot accumulate work experience because they are not being hired.

According to NSI data, for the first quarter of 2018, the employed aged $15-64$ were 3.02 million. The employment coefficient for the population in this age group is 66.5 per cent. Employment among the population aged $15-29$ is 40.3 per cent, that is, less than the half of young adults are engaged in work (http:// www.nsi.bg/bg/content).

In order to support the integration of 
young people into the labor market, a number of projects and programs have been developed. Unfortunately, in most cases, they are shortterm and cover a limited number of candidates. The period for which the programs are applied is usually between six months and a year and most often there are no follow-up projects, so the young fall back into unemployment. The clarification of the key stakeholders (Freeman, 1984), who influence the successful professional realization of young people, their roles and their functions and opportunities for impact, would be helpful in developing more sustainable measures.

The transition from education to employment is usually a period marked by shock and uncertainty when the graduates leave the structured academic environment and enter a new organizational environment where they are expected to quickly master completely different roles. The transition period may be of varying duration and go through different stages. The International Labor Organization describes it as transition of young people (1529 years) from completing education to the first sustainable or satisfactory job.

The transition from higher education to professional realization is accompanied by various obstacles of a different nature. According to the latest results (2019) of the "Ranking System of Higher Education Institutions in Bulgaria" (https://rsvu.mon. $\mathrm{bg} / \mathrm{rsvu} 4 / \# /)$, most of the graduates of higher education do not work in their specialty and are employed in positions requiring lower qualification. The lowest is the employment of graduates in the "Tourism" specialty, less than a quarter of the tourism graduates work in their specialty. At the same time, interest in this specialty is high. There are similar low realizations in many other fields such as "Biological Sciences", "Chemical Sciences", "Animal Husbandry", "Crop Production", "Plant Protection", "History and Archeology", "Religion and Theology", "Philosophy". In the fields that are generally preferred by young people, such as "Economics", "Administration and Management", "Tourism", "Law", "Psychology", nearly one-third of all students study. Students in "Medicine" and "Pedagogy" are increasing, which are among the sectors classified as deficient by staff. Unlike medical professionals who work mainly in their field of study, about $40 \%$ of graduates work something else.

Several conclusions can be drawn. On the one hand, there is a discrepancy between preferences for young people's majors, the accumulation of many students mainly in humanities and social sciences who, after graduation, cannot find a job because of the fact that the labor market is saturated with such specialists. The other problem is that the university graduates do not approve the settlement or the institutions in which there are vacancies or do not approve the payment offered to them. At the same time, according to employers, young people do not have the necessary qualifications and skills.

The information provided clearly shows that there is a mismatch of the skills supplied under the graduates and the demand for skills as preferred business specialists on the other side. The discrepancy between demand and supply of work for higher education staff leads to the conclusion that greater alignment of the higher education delivered with the needs of employers is necessary.

\subsection{The Regional Context of Life- long Learning and the Skills Systems}

Two functional regions (FRs) are presented in this article: Blagoevgrad and Plovdiv. The Blagoevgrad functional region corresponds to the Blagoevgrad district. The Plovdiv functional region corresponds to the municipality of Plovdiv and its links in the business zone Trakia. The two functional regions were chosen in this way because of the established labour market and other functional flows within the corresponding territories and in order to have a comparable population size which is 341625 inhabitants for Plovdiv and 312831 for Blagoevgrad. The two functional regions differ in several ways: Plovdiv FR is located in Central Bulgaria, while Blagoevgrad FR is located in Southwestern Bulgaria, bordering Macedonia and Greece. Plovdiv FR is an urbanized environment characterized by developed industry and services, while in Blagoevgrad FR urbanized and rural areas with developed agriculture occur. The population in both regions is an active participant in the local and regional environment and is involved in the implementation of lifelong learning programs aimed at increasing employment, improving quality of life and developing living conditions.

The structural relationships and the link between attainment of qualifications, and the labor market sectors are implemented by various institutions that develop skills and interact with social actors who have the potential and resources to influence the process 
of training young adults.

Different organizations have varying degrees of participation in skills formation. The main institutions focused on educational and training activities as well as the creation of professional culture are: South-West University "N. Rilski", regional colleges and vocational schools and high schools in Blagoevgrad region. In addition, there is a significant involvement of private organizations from non-formal learning, mainly involved in foreign language and computer education.

The process of creating skills for the labor market also includes a wider pool of organizations. These are: the Blagoevgrad Employment Agency and the Labor Office, which are actively involved in the formation of qualifications and skills. These structures are regional divisions of the Ministry of Labor and Social Policy and their activities are concentrated in a local context. They establish contacts with municipal authorities, with private businesses in the region, as well as with educational institutions, and implement various policies and projects that have national and European funding and target the population of different ages, with different qualifications and education. The activities of these structures are focused on attracting young people, improving their skills and qualifications, as well as developing knowledge among unemployed and unskilled people. The projects implemented are related to the activation of all stakeholders. The aim is to stimulate socially disadvantaged groups who have serious difficulties with their adaptation and social inclusion.

Another participant in the skills system is regional business, which is an essential component of all local structures. Regional business is a recruitment environment, it creates the conditions for the development of local infrastructure itself and is an active participant in the programs of the Labor Office. In addition, the regional business is also linked to the development of charity actions.

In terms of regional skills development, there can be a gap between training and labor market expectations. This is due to the underdevelopment of the economy and not particularly the long-term vision of the business regarding its development. In recent years, the development of regional business has been accompanied by small investments, reduced labor needs, closure of industries and entire sectors. In addition, training institutions carry out the educational process without following changes in the economic environment and train non-converting staff.

Regional Education Management (REM) is a structure that is also relevant to the system of skills formation in the Blagoevgrad district. Its functions are aimed at maintaining link and coordination between the Ministry of Education and secondary schools, as well as the municipal authorities in the region.

The mentioned structures of the system for skills formation are actively involved in the implementation of projects for the integration of young people, for the formation of qualifications and professional habits. The idea behind the various projects and programs is to create staff for regional businesses and organizations, to stimulate the overall development of the local environment and economy. The programs presented in this article show their different specifics, as well as various difficulties in their implementation (Milenkova and Apostolov, 2018).

\subsubsection{Career Start program}

The Career Start program is targeted at young people under 29 who have completed their higher education but have not started a job and have no professional experience. Applicants can submit their documents to the Regional Labor Offices. The program aims at hiring young people for a period of 9 months in central and regional public administration units and structures. The project is a long-term measure aimed at the continued stabilization of the labor market and economy in the country and regions.

The project Career Start in Blagoevgrad region is focused on preventing labor market dequalification among young adults, the hiring (after completing the program) a part of youth on permanent job positions, attainment of a qualifications, training and experience that meet the expectations of the labor market and market economy. The program has been introduced since 2003 and applies to all Labor Offices in the country. It is aimed at young adults who have no vocational experience after completing their higher education. The main objectives of the program are: to create employment for young people, as well as to acquire working habits and training, expanding the knowledge and skills created so far in formal and non-formal education. This program is highly appreciated and takes into account its effectiveness and sustainability, both by local office in the functional region 
Blagoevgrad and in other employment structures in national and regional context. One of the main reasons is that many young adults who have been involved in the project remain employed in public administration structures.

Following the information given by Employment office directorate in Blagoevgrad in 2009 only 35 graduates were involved in the program in the district. After 2014 this figure increased to 84 in 2015, 99 in 2017 and 104 in 2018.

"The Career Start project provides young adults with the opportunity to acquire practical skills, to form work experience and training that are important to the profession, in order to be successful in their field, and to be employed on a full-time basis." (Expert, female).

A major requirement of this program is that young people are under 29 years of age at the time of application. In addition, they must have a university degree in higher education, apply for a position that requires higher education and have no professional experience in the field. This means that they have not been hired to such a position so far.

"This project helped me a lot. As I graduated, I started looking for a job and for a long time I traveled through different companies and organisations to look for a job. It turned out to be a tough thing. . . When I started looking for work in the summer of 2016, I faced serious problems. I was not from Blagoevgrad and when I finished my education I had to vacate the dormitory and then it became very difficult - I have no job, I do not have a home, I have no income. Well, my family - parents and relatives supported me mostly financially so I can handle it. And then a friend told me about this programme. This programme saved me" (Young adult, female).

The interviewed experts said that the young people who participated in the program gave a positive assessment of the project and were satisfied with their participation, as it is a useful professional choice and skill development.

„In my view, young people's involvement in this program is linked to the fact that they actually define it useful; but here I want to emphasize also that these programs are generally important in regional and national level, because when young people have jobs and good pay, they do not seek work abroad." (Expert, male).

There are many examples that can be cited in relation to the successful participation of young people in the project.

Overall, it can be said that the interviews conducted with young people who participated in the Career Start project, as well as with experts who are employees of the Labor Office and worked on the implementation of the project, express a positive attitude and assessment of the program. The opinions are clear and definite. In addition, the project is also positively evaluated at national level in terms of its sustainability. What creates some problems is the fact that not all participants in the program are employed on a permanent basis and this inevitably creates frustration for young adults. This means that after the end of the program, some young people participating in it are out of work again. Solving the problem requires state support through a variety of incentives, tax breaks, or covering part of the insurance contributions at the expense of the employer for a certain period. This will provide a bridge between the temporary and permanent employment of young people, which in the long run will result in clear and lasting results from the efforts made and the return on the investments which have been made.

Another problem related to the skills system for young people in the functional region of Blagoevgrad relates to the education system and in particular the availability of much theoretical knowledge in training. Students and observers, as well as various experts, share that the Bulgarian education in the formal learning system is very theoretical, the practical classes are insufficient and the productive relationships between the universities and the business are insufficiently developed.

The functional region of Plovdiv was defined on the basis the established functional relations between the main economic, cultural and policy institutions in the region. It consists of the municipality of Plovdiv and the surrounding industrial enterprises, forming the Trakia Economic zone. Plovdiv is the second largest city in Bulgaria situated in the South-Central region of the country. After the economic crisis of 2008, the economy of the region slowly recovered and at present the private and public businesses in the functional region attract daily commuters from an even wider territory. It is a major railroad junction and has a regional airport which together give the region many logistic advantages. The economy of the functional region has a significant share of industry with an output 
over 7 billion EUR in 2017 and over a third of the employment in the region. The share of services in the regional economy is also growing with the IT sector attracting highly skilled labour force. Tourism is also gaining economic importance and has received a boost from the choice of the city to be the European Capital of Culture in 2019.

The basic structures included in the system of skill formation in the Plovdiv functional region are the local authorities, the Labor Office and the Municipality of Plovdiv. The Labour Office organizes different qualification courses for unemployed people. There are also private labour offices, which function it is to provide information about vacancies in the private sector. They interview the applicants and referred to the meeting with the employer at the appropriate persons The skills system in the region on the supply side includes 9 regional universities and colleges, 14 vocational schools and various private institutions for qualification and training. Vocational schools are defined as the main structures that prepare workers with qualifications in secondary education. There are different private structures for acquiring knowledge and skills in different profiles within the region. On the other side, young people, most often, are those who seek to enhance their knowledge and skills. They are enrolled in institutions of formal and nonformal education that are accredited in terms of the quality of the training provided. Local employers and municipal authorities are also included in the system of skills formation as active users of trained staff.

There are also many NGOs involved in the Skill Formation System. They vary in size and activity. The main activities of these NGOs are related to the implementation of various programs of social importance and funded from different sources. They hire mainly young adults, and offer them an opportunity to be particularly trained in various practical courses, or if they are still studying - to use and enhance their training in a real practical environment. NGOs work with various public entities, training units and other NGOs in the region. Some of the NGOs are focused on organizing a variety of trainings for the acquisition and learning of knowledge, upgrading skills and developing qualifications of young people, such as: soft skills, entrepreneurship skills, leadership skills, etc.

The skills formation institutions, as they are embedded in a broader network of social connections, influence local structures and create connectivity between local institutions, but sometimes they cause some difficulties due to their poorly timed activities and insufficient capacity. Educational institutions have an interest in enhancing contacts and relationships with public and private employers, but such efforts are not always fruitful. At the same time, business organizations do not turn to training structures to provide them with highly educated and qualified staff. Usually, they prefer to offer qualification courses by themselves. NGOs, being smaller in size, can be more mobile, responsive to the demand for educational services and concentrate their efforts on activities that are more appropriate and equivalent to the preferences of young people. At the same time, it is noticed that the teaching and educational structures themselves do not develop enough contacts, do not seek sustainable mutual benefit of cooperation in teaching, and in cases where there is some interaction, it often refers to activities outside the learning. This leads to the distance of the subjects who train and form skills.

The coordination of the whole system remains underdeveloped. The national policy focuses on strategies and directives, without offering specific tools for elaborating the national skill system. This limits the opportunities of the regional system to be more flexible and to respond quickly to rising market needs. Another problem is the lack of information that can circulate freely between all participants. Each project represents a constant movement between the different levels: national-regional-local. According to the project participants, due to the fact that there are several levels of hierarchy, information is interrupted at some of the levels and this creates some difficulties.

\subsubsection{Youth Guarantee Program}

The primary objective of the Youth Guarantee which is a European-wide program is to achieve early intervention in the situation of young people up to 29 years of age by including them in quality training, internships, apprenticeships or work, up to 4 months after becoming inactive or unemployed. The ambition is to fill the gap between the educational system and the labor market. The programs and measures under the Youth Guarantee are financed by the national budgets of the Member States, with additional ESF funding and the Youth Employment Initiative. 
The Regional Employment Agency in Plovdiv is responsible for the implementation of the regional active labor market policy, including the programs and measures directed to young people. There are two schemes developed in the region under the Youth Guarantee: 'Youth Employment' and 'Youth Training and Employment'. Both schemes are targeting registered unemployed but the latter also has a strand that tries to reach over the young people not in education, employment and training. The local authorities considered that the program provided a comprehensive set of services: career guidance for young people; acquiring professional skills and habits or key competences; financing and maintaining temporary employment; stimulating employers to create new jobs; support to start up an own business and develop business ideas; provision of information and advice by the EURES network.

The interviewed practitioners working in the Regional Labor Office expected a positive effect of the program by increasing youth employment and hence reducing the number of those threatened to fall into poverty. They also pointed that the schemes bring about a reduction of the number of early school leavers, particularly among the Roma youth. These effects are a precondition for creating sustainable development and minimizing cases where young people are excluded from the economic and social system.

The project is associated with high expectations to contribute to the solution of other regional problems as well, most importantly to reduce the high emigration wave of predominantly young people from the region. As one of the experts said:

"Somehow this project is related to the demographic problem here, the aging of the population, respectively the "brain drain". Out employers suffer from the lack of qualified and youthful labor force." (Expert, male).

What experts consider that the program has not yet achieved is reach over to the least qualified and particularly to the Roma youth.

The importance of the Youth Guarantee and measures and practices in this regard stimulate the ambition of the participants to achieve their aims. It should be noted that improving the qualifications of young people, developing their skills is of great importance. Internships and trainings are a good way to achieve this and to use the labor force in the overall production process. It is important for young people to gain experience in their years of study. Labor market efficiency can be achieved in cases where there is a cross-match between the skills sought and the training and qualification levels offered. This means that the main structures involved in skills training and skills seeking have come to an agreement.

However, from the analysis of the interviews with young beneficiaries in the program, we found several other problems in the implementation of the Youth Guarantee. Some young adults in Plovdiv claimed that their decision was made under a pressure coming from their actual or potential employers. When young people applied for jobs that matched their training and experience, employers persuaded young applicants to apply and apply for a Youth Guarantee Program, rather than being hired and contracted. Thus, interviewed minority men say they have been enrolled in a Youth Guarantee Program at the initiative of their employers, who will save money on working and insurance benefits for Roma workers.

A consequence of the program, according to the interviewed young people, is that it does not always help them achieve the goals they have set out and aim for. Some of the young people who expected to be hired after completing the training had not received an offer and had to re-register with the employment office as unemployed or to start other training. According to young people, this is not favorable to themselves, nor does it have an effect on the business or the running program.

When the young interviewees tried to evaluate the program as a whole, they were positive about the concrete occupation skills that they acquired during their participation in the Youth Guarantee in the region. In addition, young adults understand that their inclusion in the Youth Guarantee Program brings many positive things personally. On the one hand, these are professional skills and qualifications, and on the other hand, many skills are formed, related to their ability to communicate and create connections, to plan different things in life, self-confidence, prestige, learning new things. Some even mentioned that the result was no less than knowledge "how to become a better person" (Young adult, male).

\section{DISCUSSIONS}

From results of the analysis presented in this article, it is clear that the integration of young people in the labor market continues to be a huge challenge in Bulgaria. Even some 
of the young adults with prestigious education often find themselves unprepared for the job market. The most common problem in undergoing the school-to-work transition is the discrepancy between expectations and reality. Low pay for labor leads to demotivation. Another problem is the impossibility to find a job in the acquired specialty. Difficulties in the youth transitions in Bulgaria often lead young adults to leave the country in search of better working and living conditions (Kovacheva and Hristozova, 2019). The dynamic nature of modern labor markets raises the need for better programs to ease the early integration of young people. Their job inclusion is seen as a key prerequisite for the successful reduction of the share of people living at risk of poverty, material deprivation or a strong dependence on social assistance systems.

This article contributes to the discussions about young adults' transition from education to employment, using theoretical analysis and empirical results based on an international European Horizon 2020 study, which finds that labour market demand impacts the effectiveness of LLL policies (Parreira do Amaral and Kovacheva, 2019).

\section{CONCLUSION}

The idea of this article was to show that the success of youth transitions is linked to various programs that support the integration of young people into the labor market. The overall vision of the article was to emphasize the critical approach in tracking the transition from education to employment in Bulgarian contexts complemented by the institutional perspective of the skills system.

The policies that have been studied in the Blagoevgrad and Plovdiv regions have European funding and regulations and are promoted both on the national and the regional level. In general, the presented programs can be considered as good examples related to providing opportunities for higher qualification, formation of professional experience, creation work habits and soft skills, through internship programs in various business structures and organizations, strengthening the links between the employers' needs and the competences of young people. The reviewed initiatives are aimed at young people who are not only unemployed but also targeting active and inactive youth and socially excluded and vulnerable people who are experiencing serious difficulties in its implementation and life paths.

Looking more closely and using qualitative data from experts and young participants the picture shows various discrepancies. The practitioners implementing the schemes do not have the necessary specialized skills to deal with vulnerable groups and instead work with all age groups in need of training. On their part the young adults are excluded from the LLL policy making process and their voices on the implementation and its social effect are not heard. A significant challenge lies in the fact that, after completing the internship, the organization or the company in which the traineeship is carried out recruits few young trainees. In addition, the selection process for applicants for internships is not transparent, and decisions are made by the organization where the internship will take place and the openings are very limited so that not everyone who wishes can go through the wishes internship.

Regarding the mismatch between education and labor market needs, it can be summarized that the legal and macro political framework (e.g. laws and strategies) is focused on educational results; there is no explicit dialogue between structures and levels of education in a vertical and horizontal aspect, which means that there is not enough cohesion between them. All of this is an indicator that there are challenges to the practical side of lifelong learning policies and programs that must meet the needs of young adults. In addition, Bulgarian formal education is a closed system that functions independently from the non-formal education. On the other hand, programs, in their entirety, have results, achievements and strengths, which, while complemented by some weaknesses and shortcomings, manage to stimulate young people.

As a result, the answer to our research question is that the lifelong programs and initiatives developed on the regional level could fill in the gaps left from the deficiencies of the national skills system and to serve well the objective to support youth transitions from education to employment. More systematic schedule is needed, longer-term vision, more focused strategies on how to develop the skills of individuals. Bulgarian education is not always able to meet the new requirements and to take effective account of changes. In this sense, complicating the responsibilities, the work and the nature of the obligations becomes a prerequisite for the effective skill system. 


\section{ACKNOWLEDGEMENTS}

The analysis is based on the results of the project "YOUNG ADULLLT - 'Policies Supporting Young Ādullts in their Life Course', team coordinator Prof. Marcelo Parreira do Amaral, Ph.D., under the Horizon 2020 Program, 2016-2019.

The authors gratefully acknowledge the support of the project "YOUNG ADULLLT - 'Policies Supporting Young Adüllts in their Life Course', funded by the European Union's Horizon 2020 research and innovation programme under Grant agreement № 693167 (2016-2019).

\section{Conflict of interests} interest.

The authors declare no conflict of

\section{REFERENCES}

Benneworth, P., \& Jongbloed, B. W. (2010). Who matters to universities? A stakeholder perspective on humanities, arts and social sciences valorisation. Higher Education, 59(5), 567-588. https://doi. org/10.1007/s10734-009-9265-2

Boyadjieva, P., \& Ilieva-Trichkova, P. (2015). Institutional diversity and graduate employability: the Bulgarian case. In Diversity and Excellence in Higher Education (pp. 153171). Brill Sense. https://brill.com/view/book/ edcoll/9789463001724/BP000010.xml

Boyadjieva, P., \& Ilieva-Trichkova, P. (2019). (Un) realized agency in a situation of early job insecurity: patterns of young people's agency regarding employment. In Youth Unemployment and Job Insecurity in Europe. Edward Elgar Publishing. https://doi. org/10.4337/9781788118897.00012

Corbin, J. M., \& Strauss, A. (1990). Grounded theory research: Procedures, canons, and evaluative criteria. Qualitative sociology, 13(1), 3-21. https://doi.org/10.1007/BF00988593

Delors, J., Mufti, I. A., Amagi, I., Carneiro, R., Chung, F., Geremek, B., Gorham, W., Kornhauser, A., Manley, M., Quero, M. P., Plique, M.-A. S., Singh, K., Stavenhagen, R., Suhr, M. W., and Nanzhao, Z. (1996). Education: The Treasure Within, Paris: UNESCO, https://unesdoc. unesco.org/ark:/48223/pf0000102734

European Centre for the Development of Vocational Training (Cedefop). (2010). The skill matching challenge: Analysing skill mismatch and policy implications. Office for Official Publications of the European Communities, Luxembourg. https://www.cedefop.europa.eu/files/3056 en.pdf

European Commission (EC) (2000). A Memorandum for Lifelong Learning. European Communities, Brussels: Directorate General Education and Culture, https://arhiv.acs.si/dokumenti/ Memorandum on Lifelong Learning.pdf

European Commission ${ }^{-}$(EC) (2001). Making a
European Area of Lifelong Learning a Reality. Communication from the Commission, Brussels: COM (2001) 678 final, https:// eur-lex.europa.eu/LexUriServ/LexUriServ. do?uri=COM:2001:0678:FIN:EN:PDF

Eurofound (2014). Mapping Youth Transitions in Europe. Luxembourg: Publications Office of the European Union, https://www.eurofound. europa.eu/publications/report/2014/labourmarket/mapping-youth-transitions-in-europe

Federation, M. E., Radovic, M., \& Djuraskovic, J. (2015). Report: Mismatch between Education System and Labour Market Needs-Enabling Environment for Sustainable. Education, 7. http://poslodavci.org/en/publications/mismatchbetween-education-and

Freeman, R. E. (1984). Strategic Management: A stakeholder approach. Boston: Pitman.

Klapka, M. P., Halás, D. R. M., \& Tonev, M. P. (2013). Functional regions: Concept and types funkční regiony: koncept a typy. XVI. mezinárodni kolokvium o regionálních védách, 94. https:// doi.org/10.5817/CZ.MUNI.P210-6257-2013-11

Kogan, I., Noelke, C., \& Gebel, M.(Eds.).(2011).Making the transition: Education and labor market entry in Central and Eastern Europe. Stanford University Press. https://doi.org/10.11126/ stanford/9780804775908.001.0001

Kovacheva, S. (2001). Flexibilisation of youth transitions in Central and Eastern Europe. Young, 9(1), 41-60. https://doi. org/10.1177/110330880100900104

Kovacheva, S., \& Hristozova, D. (2019). Youth migration and life course transitions: Comparing the impact of women's mobility across generations in Bulgaria. Sociologija, 61(2), 210226. https://doi.org/10.2298/SOC1902210K

McLoughlin, C., \& Luca, J. (2002). A learner-centred approach to developing team skills through web-based learning and assessment. British Journal of Educational Technology, 33(5), 571582. https://doi.org/10.1111/1467-8535.00292

Milenkova, V., \& Kovacheva, S. (2020). Regional Insights to Lifelong Learning Policies in Support of Young Adults in Bulgaria. Sofia: Avangard Prima.

Milenkova, V., \& Apostolov, G. (2018). Implementing Youth Targeted Education and LLL Policies at Regional Level. Strategies for policy in science and education-strategii na obrazovatelnata $i$ nauchnata politika, 26(2), 146-165. https://strategies.azbuki.bg/en/staregies/ sonparticles2016-3/xxvi-2-2018/\#art02

Mitev, P.E., B. Popivanov, S. Kovacheva and P. Simeonov (2019). Bulgarian Youth. A Sociological Portrait 2018/2019. Sofia: Friedrich Ebert Foundation, http://library.fes.de/pdf-files/id-moe/15263.pdf

Morgado, A., Sequeira, T. N., Santos, M., FerreiraLopes, A., \& Reis, A. B. (2015). Measuring labour mismatch in Europe. Social Indicators Research, 129(1), 161-179. https://doi. org/10.1007/s11205-015-1097-0

Outlook, O. O. R. (2016). Productive regions for inclusive societies. https://www.oecd. org/regional/oecd-regional-outlook-20169789264260245-en.htm

Parreira do Amaral, M., \& Kovacheva, S. (Eds.). (2019). Lifelong Learning Policies for Young Adults in Europe: Navigating between Knowledge and Economy. Policy Press. 
Milenkova, V., \& Kovacheva, S. (2020). Youth and the skills system in Bulgaria. Can lifelong learning policies on the regional level compensate for the mismatches in the national skill system?, International Journal of Cognitive Research in Science, Engineering and Education (IJCRSEE), 8(1), 49-60

Roberts, K. (2018). Explaining Education-to-Work Transitions: Thinking Backwards, Situating Agency and Comparing Countries. Review of European Studies, 10(1), https://doi.org/72. $10.5539 /$ res.v10n1p72

Schomburg, H., \& Teichler, U. (2007). Higher education and graduate employment in Europe: results from graduates surveys from twelve countries (Vol. 15). Springer Science \& Business Media. https://doi.org/10.1007/978-1-4020-5154-8

Stoilova, R., \& Nyagolov, L. (2016). Socio-professional Differences of School-to-Work Transitions. Sociological Problems, 48.

Tholen, G. (2015). What can research into graduate employability tell us about agency and structure?. British Journal of Sociology of Education, 36(5), 766-784. https://doi.org/10.1 080/01425692.2013.847782

Tomlinson, M. (2017). Introduction: Graduate employability in context: Charting a complex, contested and multi-faceted policy and research field. In Graduate employability in context (pp. 1-40). Palgrave Macmillan, London. https://doi. org/10.1057/978-1-137-57168-7 1

Tomanović, S. (2019). Reconstructing changes in agency in the young people's social biographies through longitudinal qualitative research. Young, 27(4), 355-372. https://doi. org/10.1177/1103308818793304

Walther, A. (2006). Regimes of youth transitions: Choice, flexibility and security in young people's experiences across different European contexts. Young, 14(2), 119-139. https://doi. org/10.1177/1103308806062737 